\title{
Effect of Service Quality on Integrated Antenatal Care Patient Satisfaction
}

\section{Murti Dwi Handayani, Sentot Imam Suprapto, Nia Sari}

Mojokerto, Indonesia

Email: dwimurti1975@gmail.com

Received : March 12, 2019

Accepted : October 13, 2019

Published : November 26, 2019

\section{ABSTRACT}

The increase in the health service is very important to be made by health care provider institutions such as clinics in order to improve patient satisfaction. But in the last few years many decline the number of visits the patient at the clinic. This is due to the existence of the dissatisfaction felt by the patient over a given service. The purpose of the study to find out the influence of the quality of service to the satisfaction of the Patients current study. Design Integrated ANC namely observational analytic quantitative approach. The research of the variable quality of service as the independent variable and the dependent variable as patient satisfaction. The population of the research that is Integrated in the entire patient ANC Clinics Kupang (nutrition, BP, KIA, LAborat and Loket) Mojokerto with the average number of patients per month as many as 777 patients. Smapel taken with the technique of systematic sampling as much as 117 respondents. Data collected by questionnaire instrument and processed by using coding, editing, tabulating and scoring as well as tested with test statistic spearman rho and linear regression. Research results throughout the dimensions of service quality affects patient satisfaction whereas that can be seen from the value of $\rho$ value $<$ 0.05 for all dimensions so partial dimensions of service quality affects patient satisfaction. Similarly, on the results of the regression simultaneously or synchronously also showed the same results, namely the value of $\mathrm{p}$ value $<0.05$, so can be conclusion that simultaneously or synchronously dimensions of service quality affects patient satisfaction.

Keywords: Service Quality, Satisfaction of Patients, Antenatal Care Integrated

\section{(). (1) (-)}

This is an open-acces article distributed under the terms of the Creative Commons Attribution-ShareAlike 4.0 International License. 


\section{INTRODUCTION}

Quality of service is very important in realizing customer satisfaction. In an environment that is increasingly full of competition, especially health services agency Clinics which is the first Ministry of health problems in the community against must be increasingly aware of the importance of providing quality the best services for its customers. The increase in the health service is very important to be made by health care provider institutions such as clinics in order to improve patient satisfaction. But in the last few years many decline the number of visits the patient at the clinic. This is due to the existence of the dissatisfaction felt by the patient over a given service. This dissatisfaction occurs because services provided by health care establishments is still less than the expectations of patients like the service long enough, the queue at the counter and BP long, less lounge facilities comfortable and clean, the clerk at the BP, and other poly still less friendly and less adept against the patient, and the patient must also wait for the results of a fairly long laborat. Such circumstances affect the attitude and response of the patient against the Ministry received so that the patient's dissatisfaction arises.

Although the development of clinics already shows the level of development of adequate facilities, but it appears that the utilization of clinics by the public is still not optimal. This situation also occurred in Kupang where number of visits of clinics inpatient maternity in 2016, there is as much as 2 public and patients in 2017 rose to 6 patients. The above observation results show decline in inpatient visits of clinics Kupang Regency Mojokerto. A preliminary study undertaken in July 2018 researchers note that the number of pregnant women at the Clinic monthly average Mussel as much as 262 patients do MCH ANC integrated as much as 37 people per month. Service of process a registration beginning with the ANC which was continued with an examination by midwife to get ANC services that include blood pressure checks, weight checks, weighing leopold, and the granting of iron. In accordance with the standards set forth by the ANC of Minister Of Health at Indonesia in 2010. The results of the interview against the 10 pregnant women who perform the inspection of the ANC about how midwives serving an examination of the ANC, as 6 of the mother $(60 \%)$ said midwives less attention and less nimble, the queue at the counter of the old and unoccupied, the attitude of the officers who are less friendly, quick response, and friendly, while the 4 moms (40\%) said the midwife, and friendly attention enough in serving the examination queue at the counter of the ANC, not too long.

Based on the background of researcher interested in doing further research on "the influence of the quality of service to the satisfaction of the Integrated ANC patient's in Kupang Public Health Center of Kupan at Mojokerto City".

\section{MATERIALS AND METHODS}

Design Integrated ANC namely observational analytic quantitative approach. The research of the variable quality of service as the independent variable and the dependent variable as patient satisfaction. (Donsu, Jenita Doli Tine. 2016). The population of the research that is Integrated in the entire patient ANC Clinics Kupang (nutrition, BP, KIA, LAborat and Loket) Mojokerto with the average number of patients per month as many as 777 patients. Smapel taken with the technique of systematic sampling as much as 117 respondents. Data collected by questionnaire instrument and processed by using coding, editing, tabulating and scoring as well as tested with test statistic spearman rho and linear regression..

The assessment service is done by using the likert scale and the classification of service good, sufficient and less. While the penilaia satisfaction is also using likert scale with the classification assessment satisfied, fairly satisfied, and less satisfied. 
RESULT

Coefficient of Correlation

Table 1 The Coefficient of Correlation Dimensions of patient Satisfaction with the quality of service of integrated ANC Patients at Kupang Public Health Center of Mojokerto City On Oktober $2018(n=117)$

\begin{tabular}{|c|c|c|c|}
\hline Room & Variabel X & Variabel Y & $\begin{array}{c}\text { Coefficient of } \\
\text { Correlation }\end{array}$ \\
\hline \multirow[t]{5}{*}{ Nutrition } & Tangible & Satisfaction & 0,522 \\
\hline & Assurance & Satisfaction & 0,561 \\
\hline & Reliablity & Satisfaction & 0,558 \\
\hline & Responsiveness & Satisfaction & 0,510 \\
\hline & Emphaty & Satisfaction & 0,663 \\
\hline \multirow[t]{5}{*}{ Bp Room } & Tangible & Satisfaction & 0.500 \\
\hline & Assurance & Satisfaction & 0.459 \\
\hline & Reliablity & Satisfaction & 0.585 \\
\hline & Responsiveness & Satisfaction & 0.573 \\
\hline & Emphaty & Satisfaction & 0.616 \\
\hline \multirow[t]{5}{*}{ KIA Room } & Tangible & Satisfaction & 0.451 \\
\hline & Assurance & Satisfaction & 0.551 \\
\hline & Reliablity & Satisfaction & 0.586 \\
\hline & Responsiveness & Satisfaction & 0.455 \\
\hline & Emphaty & Satisfaction & 0.610 \\
\hline \multirow[t]{5}{*}{ Laboratory Room } & Tangible & Satisfaction & 0.450 \\
\hline & Assurance & Satisfaction & 0.543 \\
\hline & Reliablity & Satisfaction & 0.486 \\
\hline & Responsiveness & Satisfaction & 0.304 \\
\hline & Emphaty & Satisfaction & 0.668 \\
\hline \multirow[t]{5}{*}{ Counter Room } & Tangible & Satisfaction & 0.254 \\
\hline & Assurance & Satisfaction & 0.330 \\
\hline & Reliablity & Satisfaction & 0.304 \\
\hline & Responsiveness & Satisfaction & 0.379 \\
\hline & Emphaty & Satisfaction & 0.354 \\
\hline
\end{tabular}

Based on the results in table 1 shows that the value of the correlation coefficient on the space the most nutrition high is in the dimension of 0.659 emphaty. On the space koefeisien the highest correlation on BP dimensions of 0.608 emphaty and in space the highest correlation coefficient value KIA on the dimension of responsiveness of 0.377 . On the space at the highest coefficient value laborat dimensions on the dimensions of 0.659 emphaty and counter space dimensions with the highest coefficient value is on ddimensi sebesra 0.611 empathy. The results of this research indicate that all the dimensions in the service room integrated the ANC has a fairly strong correlation

fairly strong correlation

\section{Bivariat Analysis}

Tabel 2 Bivariat Analysis With Spearman Rho test about Dimention OF service Quality with Satisfaction of integrated ANC Patients at Kupang Public Health Center of Mojokerto City On Oktober $2018(n=117)$

\begin{tabular}{cllc}
\hline \multicolumn{1}{c}{ Ruang } & \multicolumn{1}{c}{ Variabel X } & Variabel Y & P value \\
\hline Nutrition & Tangible & Satisfaction & 0,000 \\
\hline & Assurance & Satisfaction & 0,000 \\
\hline
\end{tabular}




\begin{tabular}{llll}
\hline & Reliablity & Satisfaction & 0,000 \\
\hline & Responsiveness & Satisfaction & 0,000 \\
\hline Emphaty & Satisfaction & 0,000 \\
\hline & Tangible & Satisfaction & 0,000 \\
\hline & Assurance & Satisfaction & 0,000 \\
\hline & Reliablity & Satisfaction & 0,000 \\
\hline Responsiveness & Satisfaction & 0,000 \\
\hline & Emphaty & Satisfaction & 0,000 \\
\hline & Tangible & Satisfaction & 0,000 \\
\hline & Assurance & Satisfaction & 0,000 \\
\hline Laboratory Room & Reliablity & Satisfaction & 0,000 \\
\hline & Responsiveness & Satisfaction & 0,000 \\
\hline & Emphaty & Satisfaction & 0,000 \\
\hline Tangible & Satisfaction & 0.000 \\
\hline Assurance & Satisfaction & 0.000 \\
\hline Counter Room & Reliablity & Satisfaction & 0.000 \\
\hline & Responsiveness & Satisfaction & 0.001 \\
\hline & Emphaty & Satisfaction & 0.000 \\
\hline Tangible & Satisfaction & 0,006 \\
\hline & Assurance & Satisfaction & 0,000 \\
\hline & Reliablity & Satisfaction & 0,000 \\
\hline & Responsiveness & Satisfaction & 0,001 \\
\hline & Emphaty & Satisfaction & 0,000 \\
\hline
\end{tabular}

Based on the results in table 2 show that the $\mathrm{P}$ value overall dimensions of service quality so that $0.05<$ this indicates that $\mathrm{H} 1$ is accepted and $\mathrm{H} 0$ is rejected that the dimensions of service quality (tangible, realibitliy, responsiveness, assurance, and emphaty) affects patient satisfaction ANC Clinics integrated in Kupang Regency Mojokerto. The results of this research show the bahwsannya all the dimensions of service quality affects patient satisfaction in all ministries of the ANC.

\section{Multivariat Analysis}

\section{Partially Analysis}

Tabel 3Linier regretion analysis by partially (t test) the Dimention OF service Quality with Satisfaction of integrated ANC Patients at Kupang Public Health Center of Mojokerto City On Oktober 2018

\begin{tabular}{llcc}
\hline \multicolumn{1}{c}{ Room } & \multicolumn{1}{c}{ Dimention } & Nilai t test & P value \\
\hline Nutrition & Tangible & 2.458 & 0.006 \\
\hline & Assurance & 3.514 & 0.016 \\
\hline & Reliablity & 2.180 & 0.031 \\
\hline & Responsiveness & 3.917 & 0.008 \\
\hline Bp Room & Emphaty & 5.960 & 0.000 \\
\hline & Tangible & 2.630 & 0.010 \\
\hline & Assurance & 3.652 & 0.001 \\
\hline Reliablity & 2.142 & 0.034 \\
\hline KIA Room & Responsiveness & 3.948 & 0.014 \\
\hline & Emphaty & 3.697 & 0.000 \\
\hline & Tangible & 2.210 & 0.029 \\
\hline & Assurance & 4.751 & 0.000 \\
\hline & Reliablity & 3.802 & 0.000 \\
\hline
\end{tabular}




\begin{tabular}{llll}
\hline & Emphaty & 5.447 & 0.000 \\
\hline Laboratory Room & Tangible & 2.797 & 0.006 \\
\hline & Assurance & 3.076 & 0.003 \\
\hline & Reliablity & 1.860 & 0.065 \\
\hline & Responsiveness & 3.518 & 0.006 \\
\hline Counter Room & Emphaty & 5.809 & 0.000 \\
\hline & Tangible & 2.127 & 0.062 \\
\hline & Assurance & 2.401 & 0.064 \\
\hline & Reliablity & 3.533 & 0.009 \\
\hline & Responsiveness & 2.931 & 0.004 \\
\hline & Emphaty & 3.389 & 0.001 \\
\hline
\end{tabular}

Based on the results in table 3 show that the entire dimensions of service quality affects the satisfaction shown by all values of $\mathrm{P}$ value $<0.05$ so that by partially that's variable affects the dependent variable, independent.

\section{Smultaneously Analysis}

Tabel 4 Linier regretion analysis by partially (t test) the Dimention of service Quality with Satisfaction of integrated ANC Patients at Kupang Public Health Center of Mojokerto City On Oktober 2018

\begin{tabular}{lcc}
\hline \multicolumn{1}{c}{ Ruangan } & Nilai F test & P value \\
\hline Nutrition Room & 30.867 & 0,000 \\
\hline BP Room & 27.235 & 0,000 \\
\hline KIA Room & 37.947 & 0,000 \\
\hline Laboratory Room & 31.348 & 0.000 \\
\hline Counter Room & 10.030 & 0.000 \\
\hline
\end{tabular}

Based on the results in table 4 shows that all dimensions of service quality affects patient satisfaction can be described simultaneously good (tangible, assurance, reliability, responsiveness and emphaty) can affect satisfaction patients with significance value while the fifth room 0.05 sehinggadapat stated < simultaneously or synchronously dimensions of service quality integrated ANC tangible, assurance, reliability, responsiveness and emphaty) can affect satisfaction patients. (Ghozali, Imam. 2011)

\section{DISCUSSION}

Dimention of service Quality with Satisfaction of integrated ANC Patients at Kupang Public Health Center of Mojokerto City

Nutriton Room

Based on the results of the research show that the dimensions of service quality in the poly Nutrition obtained data on tangible dimension almost half as many as either the Ministry stating the 43 respondents (37\%). Almost half the dimension of the Assurance expressed quite well by as much as 48 respondents $(41 \%)$. On the dimension of reliability data obtained nearly half expressed quite well by as much as 55 respondents $(47 \%)$, on the dimension of responsiveness retrieved data nearly half declared both as much as 51 respondents (44\%) and good enough as much as 51 respondents (44\%) and on the dimensions of the emphati almost half expressed quite well by as much as 53 respondents (45\%) (Sari, Nia, dan Ratna Wardani. 2015).

Quality of service is the goal of an agency or institution. The quality or the quality of service provided through a good management approach into the main requirement that should not be overlooked if a service provider wants to stay can be developed and developing, the increasingly tight competition nowadays makes an institution service provider or the service seeks to be able to provide a service or services to consumers with service excellence and best (Assauri, 2013). Quality of service is an activity that is carried out to evaluate the suitability of a given service provider against the expectations of the consumer (Tjiptono, Fandy. 2014). 
The results of the research conducted in the Nutrition of patients showed that the ANC is integrated many patients expressed the services they receive is of good quality and the service is quite good. This happens because the respondent had enough understanding about how the pelayannan should be given by the officer on the space nutrition in dealing with patients so that patients feel integrated ANC services received is enough either as officers can Describes the information about nutrition that should be filled by pregnant women and various sources of nutrients that can be consumed as well as the State of the nutritional status of the mother so that the patient feels accepted service including good service and pretty good.

\section{Medical Center Room (BP)}

Based on the results of the research show that the dimensions of service quality in tangible dimensions BP Poly retrieved data nearly half declared service is quite good as much as 48 respondents $(41 \%)$. Nearly half of States Assurance dimension is quite good as much as 51 respondents (44\%). On dimnesi reliability data obtained nearly half expressed quite well by as much as 55 respondents (47\%), on the dimension of responsiveness retrieved data nearly half declared both as much as 53 respondents $(45 \%)$ and in the dimension of emphati almost half of them stated pretty good as much as 57 respondents (49\%). (Sari, Nia, dan Ratna Wardani. 2015).

The main thing is the quality of service and duty, if an agency or institution would like to forward. Something that was less true when people say the success of a service provider depends on the hard work without quality, is actually happening is that the service provider provides the maximum quality of service to the consumer, so the consumer is feeling slaked. Service quality is a means to achieve customer satisfaction. The goal is to produce a consumer satisfied and loyan and will continue to establish cooperation and using the services provided by service providers. For it's high quality of service and excellence is a thing that becomes a liability and should be made by service providers when wanting to achieve satisfied customers and loyal or faithful (Tjiptono, Fandy. 2014).

The results of this study showed that the quality of service received by patients of the ANC in the integrated treatment of the Hall include good service and pretty good. This can be seen on the basis of the respondent's statement of the bahwasaanya officers are already quite skilled in providing service and quite responsive in responding to the complaints of the patient so that the patient feels comfortable in doing the treatment in Clinics and Kupang. The dissatisfaction experienced by the respondents on the BP space occurs because there is a less friendly officers in carrying out the examination and treatment of patients as well as an explanation of the interference experienced by patients are still hard to be understood by the patient still have a background of primary and secondary education. The dimensions of service quality which is still lacking on the BP space lies in the dimension of reliability this happens because the respondents still consider that less skilled officer in carrying out the Act, officers of the less friendly in providing service and the clerk is less obvious in giving information to the patient.

\section{KIA (Mother and Child Health)}

Based on the results of research in the KIA shows that the dimensions of service quality in the KIA on tangible dimensions retrieved data most of the declared service is quite good as much as 41 respondents (35\%). The dimensions of the Assurance the majority stated stated quite well as much as 56 respondents (48\%). On dimnesi reliability of data obtained with the other States is quite good as much as 59 respondents $(50 \%)$, in the dimension of responsiveness retrieved data is largely expressed quite well by as much as 60 respondents $(51 \%)$ and on the dimensions of the emphati almost half declaring good enough as much as 52 respondents (44\%). (Sari, Nia, dan Ratna Wardani. 2015)

In the perspective of the patient, the quality of service, namely whether the health service that can fulfill what is expected of consumers as measured by the satisfaction of patients and patient complaints. The dimensions of the quality of service is more related to the assessment of the quality of health services based on each individual's perception. The quality of health care for patients more views on the dimension of the ketanggapan officers in meeting patient needs, provide an empathy, respect, smooth communication with the patient, hospitality officer officers in serving patients, and or the cure for a disease that is being suffered. Although the assessment of the quality of medical services provided to patients is subjective, but there remains a basic objective which is based by past experience, education, service and time psychic situation influence the environment (Tjiptono, Fandy. 2014). 
The results of this study showed bahwasaanya the respondent is sufficient understanding of what is required of them when they do inspections ANC integrated and it is in quite a good response by the officers in the KIA Clinics Kupang so with cpeat response and the ability of officers who can be trusted in conducting an examination of the ANC to make respondents feel confident that the services provided by the clerk in the KIA clinics Kupang include good service. The existence of integrated ANC patients feel dissatisfied occurred because patients feel there are officers who still do not provide quick and precise response against complaint experienced and perceived the patients, as well as less friendly officers in conducting the examination health. Dimensions kualtias pelayanna the effect on patient dissatisfaction or less is in the dimension of reliability this happens because the respondents still consider that less skilled officer in carrying out the Act examination on the officer's mother, less friendly and less clear in providing information to pregnant women about how to ahrus treatment carried out during pregnancy.

\section{Laboratory Room}

Based on the results of research in the laborat shows that the dimensions of service quality in tangible dimensions laborat retrieved data nearly half declared service is quite good as much as 43 respondents (37\%). Nearly half of States Assurance dimension is quite good as much as 52 respondents (44\%). On dimnesi reliability data obtained nearly half expressed quite well by as much as 54 respondents $(46 \%)$, on the dimension of responsiveness retrieved data nearly half expressed quite well by as much as 55 respondents (47\%) and in the dimension of emphati almost half of them stated pretty good as much as 53 respondents (45\%). (Sari, Nia, dan Ratna Wardani. 2015).

The quality of health services is seen from the point of view of health profession as officers of organizing health services more related dimensions of the suitability of the service, which was held with the development of cutting-edge science and technology and or the autonomy of the profession in organizing health services according to the needs of patients and to improve the degree of patient's health and society (Tjiptono, Fandy. 2014).

The results of this study indicate that respondents believed bahwsannya officer at the lab were enough skilled and capable of reliably in their task and rarely pelaksanaa of megneluh respondents that officers who are less skilled in the process of the taking of blood or other laborat action so that respondents believe that the services they received in the Ministry including laborat quite well. In addition to the patients who feel there is research on pusas patients who felt dissatisfied about a Ministry officer laborat, where this is the case because the patient feels less laborat officers can give an explanation on the patient about the function of the laboratory examination conducted and officers there are less capable of doing the taking of the blood as well as blood-taking is done in a long time. The dimensions of service quality that affects the patient's dissatisfaction and is the smallest value of the dimension is the dimension of reliability, this is the case because the respondents States that officers are less skilled in performing the Act examination Laboratory Officer, less friendly in providing service and officers are less clear in providing information to patients.

\section{Loket}

Based on the results on the space show that counters the dimensions of service quality in tangible dimensions Counters retrieved data most of the declared service is quite good as much as 66 respondents (57\%). The dimensions of the Assurance the majority stated quite well as much as 62 respondents $(53 \%)$. On dimnesi reliability data obtained nearly half expressed quite well by as much as 54 respondents (46\%), on the dimension of responsiveness retrieved data is largely expressed quite well by as much as 66 respondents (56\%) and in the dimension of the half of emphati declaring good enough as much as 59 respondents (50\%). (Sari, Nia, dan Ratna Wardani. 2015).

According to Zethaml, 2006 In Surydna (2017) States that service quality is an important element in receiving the response service provider customers such as hospitals, financial institutions, and educational institutions. If the service received exceeds customer expectations expectations then the Ministry is said to be good. If the service provided in accordance with the expectations of the customers eat the service quality is said to be ideal. And if the service provided is less meet the expectations of customers then the bad quality of service.

The results of this research show the bahwasaanya service provided by officers of the Ministry including counters are quite good although the patient should do queueing in receiving health care services, but 
the queue is not long enough so that the respondents still consider the given service good enough besides the clerk at the counter of the space friendly enough in doing service so patients feel comfortable despite having to wait in line checks the ANC because officers skilled enough and concern for the State of the patient in providing service. (Indriyani. 2013)

\section{Satisfaction of integrated ANC Patients}

Based on the results of research on patient satisfaction indicate that almost half of the respondents were satisfied with the service of nutrition in space as much as 54 respondents $(46 \%)$, almost half of the respondents were satisfied with the service at the BP as much as 54 the respondents (46\%), almost half of the respondents were satisfied with the service at the KIA as much as 54 respondents (46\%), space data obtained nearly half laborat respondents feel satisfied as much as 54 respondents ( 4650 and counter space indicates data that 63 respondents $(54 \%)$ were satisfied with the service received.

Customer satisfaction is the central concept of target marketing. So all the marketing planning and program a company aims to satisfy customers. Because customers will pay attention to the quality of service that was provided to the company (Laurent, 2005). Someone's feelings is the level of satisfaction after comparing performance or perceived results in accordance with the expectation.

The results of this study indicate that many patients feel satisfied on Ministry received mainly on the skills of the officers and the response provided in responding to the complaints of the patient, in addition officers are also friendly to the patient so patients feel comfortable in receiving services provided by the officer. According to the clerk at the health center patients are always right in providing information and therapies on patients and they did not wait for the patient to menginggatkan time to melakukna visits and drug-taking. In addition the patient felt the officers take better care of patients for example they always invite the patient speak when giving therapy so that susaana becomes not the tense and administering the therapy to be smooth. Whereas in patients who feel less happens because still there are some nurses who are less friendly, and when giving therapy they look stiff and response provided appears still a long. (Kitapci, Olgun. 2014).

\section{Influence of dimensions of service quality of patient with Satisfaction of integrated ANC Patients at Kupang Public Health Center of Mojokerto City On Oktober 2018}

Based on the results of partial $\mathrm{p}$ value shows in the whole dimension of the quality of service so that 0.05 < stated that partially or singly that all dimensions of service quality affects patient satisfaction. Simultaneously or synchronously obtained data in table 4.11 i.e. $\rho$ the whole dimension of the quality of service it can be $0.05<$ stated that together - same dimensions throughout the service quality affects patient satisfaction. Quality of service is very important in realizing customer satisfaction. In an environment that is increasingly full of competition, especially health services agency Clinics which is the first Ministry of health problems in the community against must be increasingly aware of the importance of providing quality the best services for its customers. (Yohana, Antin. 2012). The increase in the health service is very important to be made by health care provider institutions such as clinics in order to improve patient satisfaction. Patient satisfaction is the level of one's feelings after comparing the performance of the patient experience with the hope that patients want when intending to seek treatment. If the patient feels satisfied, this greatly affect an action based on the past experiences where they won't be easy to switch services because the stimulation of marketing (Bustami. 2012). This adult look clinics or other health facilities continue to strive to develop, in terms of both infrastructure capacity, along with the development of technology. Although there are developments from time to time, but the basic function of clinics remained unchanged. The basic functions of a health center is the promotion and restoration of health of members of the public, whether in inpatient services. as well as outpatient consultation, as well as maintenance or health care community members (Sugiyono. 2015). Research results in shows that the five dimensions of service quality affects the incidence of patient satisfaction where every space in the process of acceptance of the patient's ANC has integrated the most influential dimensions and differ per room. This happens because the dimensions of patient service is given in a different way from any room and officer's skills in delivering services is also different that this affected the perception of the patient in receiving health care services, especially in the process of examination of the ANC. Like the BP space, space, space nutrition and KIA'S Space laboratory services still less lies in the dimension of reliability this happens because the respondents still consider that less 
skilled officer in carrying out the action, the officer less friendly in providing service and officers are less clear in providing information to the patient. While on the space dimension of the counters that are most influential on patient satisfaction is tangible dimension where according to the waiting room diloket respondents are less comfortable and patients still wait queue long enough so that it makes patients not nayaman dak less satisfied with the service at the counter. (Yeoh, Eugene. 2013)

\section{CONCLUSION}

There is the influence of service quality dimensions againts patient Satisfaction at Integrated Antenatal Care in Public Health Centers of Kupang Mojokerto.

\section{REFERENCES}

Bustami. (2012). Penjaminan Mutu Pelayanan Kesehatan \& Akseptabilitasnya. Jakarta: Erlangga.

Donsu, Tine, J., D. (2016). Metodologi Penelitian. Yogyakarta: Pustaka Baru Press.

Imam, G. (2011). Aplikasi Analisis Multivariate. Badan Penerbit Universitas Diponegoro. Semarang.

Indriyani. (2013). Keperawatan Maternitas Pada Area Perawatan Antenatal. Yogyakarta: Nuha Medika.

Kitapci, Olgun. (2014). The Impact of Service Quality Dimensions on Patient Satisfaction, Repurchase Intentions and Word-of-Mouth Communication in the Public Healthcare Industry. Elsevier, Procedia - Social and Behavioral Sciences. Vol. 148, 161 - 169.

Sari, N. \& Wardani, R. (2015). Pengelolaan dan Analisis Data Statistik dengan SPSS. Edisi 1. Cetakan 1. Yogyakarta: Deepublish.

Sugiyono. (2015). Metode Penelitian Kuantitatif, Kualitatif Dan $R \&$ D. Cetakan ke-24. Bandung: Alfabeta.

Tjiptono, F. (2014). Pemasaran Jasa. Malang: Bayumedia Publishing.

Yeoh, E. (2013). Understanding medical tourists: Word-of-mouth and viral marketing as potent marketing tools. Elsevier, Tourism Management Vol. 34. 196-201.

Yohana, A. (2012). Analisis Harapan dan Kepuasan Paien Rawat Inap Penyakit Dalam terhadap Mutu Pelayanan Dokter Spesialis di RSI Sunan Kudus. Tesis Tidak Dipublikasikan. Semarang: Universitas Diponegoro 